\title{
The Effect of Price, Service Quality, Customer Satisfaction and Image on Customer Loyalty on the Lion Air Indonesia Airline
}

\author{
Violinne Antpnetha Dotulong ${ }^{1}$, Erna Andajani ${ }^{2 *}, \&$ Siti Rahayu ${ }^{3}$ \\ ${ }^{1}$ University of Surabaya, Surabaya, Indonesia \\ ${ }^{2}$ University of Surabaya, Surabaya, Indonesia \\ ${ }^{3}$ University of Surabaya, Surabaya, Indonesia \\ *Corresponding author. Email: ernajani@staff.ubaya.ac.id
}

\begin{abstract}
This study aims to determine and analyze the effects of price, service quality, customer satisfaction, and image on customer loyalty with the research object of Lion Air Indonesia. The type of research is basic research that uses 5 variables: price, service quality, customer satisfaction, image, and customer loyalty. This study uses primary data by distributing questionnaires online. The sample used in this study was 250 respondents. While the data processing method in this study uses the IBM SPSS and AMOS 22.0 software to perform model tests (measurement models and structural models) and hypothesis testing. The results of this study indicate that price and service quality have a positive and significant effect on customer satisfaction. Customer satisfaction has a positive and significant effect on the image. Meanwhile, customer satisfaction and image have no effect on customer loyalty and service quality has a positive and significant effect on customer loyalty.
\end{abstract}

Keywords: price, service quality, customer satisfaction, image, customer loyalty.

\section{INTRODUCTION}

The aviation industry is considered the lifeblood of a nation's economy, including Indonesia's economy, where Lion Air is one of the players in this industry and is known as Indonesia's largest private airline company. Its tagline, "We Make People Fly", is reflected in its business process. This airline focuses on prices, flight frequency, and an extensive route network throughout Indonesia.

Ticket prices are an essential element and consideration for passengers when choosing an airline (Vlachos \& Lin 2014). Affordable prices and price discounts are factors that can lead to passenger satisfaction (Mikulic \& Prebezac 2011). Akamavi et al. (2015) emphasize that price is a determinant of passenger satisfaction. Calisir et al. (2016) argue that price is an antecedent of satisfaction. This shows that affordable ticket prices will satisfy passengers more. Akamavi et al. (2015) reveal that price has a significant effect on satisfaction. Therefore, the first hypothesis developed is H1: Price has a positive effect on customer satisfaction.

Service quality is an essential factor in meeting customer needs and demands (Munusamy et al. 2011). If the service quality of an airline is bad and impolite, the customer will be dissatisfied with the airline's service (Namukasa 2013). Calisir et al. (2016) and Leong et al. (2015) state that service quality has a positive effect on customer satisfac- 
tion. Companies must provide better service quality as it is a determinant of customer satisfaction (Cronin et al. 2000, Cronin \& Taylor 1992). Customer satisfaction increases profitability, return on investment, and market share (Legoherel 1998, Stevens et al. 1995). Thus, a hypothesis can be stated as $\mathrm{H} 2$ : Service quality has a positive effect on customer satisfaction.

Image is an individual's perception of a company that has a significant impact on the company's progress and growth. Kang \& James (2004) instead of Calisir et al. (2016) stipulate that image is a key asset for any company. Calisir et al. (2016) say that customer satisfaction has a positive effect on the image. The image of an airline company can enhance the reputation of an airline company. Then the third hypothesis is H3: Customer Satisfaction has a positive influence on the image.

Customer satisfaction is often a determining factor in customer loyalty. Every satisfied customer will return to the company to repurchase the products/services offered by the company. Akamaviet et al. (2015), Forgas et al. (2010), and Namukasa (2013) show that satisfaction has a significant effect on loyalty. Some studies show that the higher the customer satisfaction, the higher the repurchase and customer loyalty (Davidow 2003, Ekiz \& Arasli 2007). Research conducted by Leong et al. (2015) reveals that customer satisfaction has a very strong direct impact on customer loyalty. This is in line with Clemes et al. (2008), Nadiri et al. (2008), and Saha \& Theingi (2009) on airline companies that show if airline passenger is satisfied then they will repurchase and uphold customer loyalty. The hypothesis that can be developed is H4: Customer Satisfaction has a positive effect on customer loyalty.

A well-known image or image in customers' minds is a key asset for any company (Kang \& James 2004 instead of Calisir et al. 2016). Mikulic \& Prebezac (2011) state that airline company image is a strong indicator of passenger loyalty. If a customer feels that he is benefited by an airline, the customer will be more likely to reuse the airline. Calisir et al. (2016) state that image is found to have a significant positive effect on customer loyalty. The formulation of the hypothesis that can be developed is H5: Image has a positive effect on customer loyalty.

Service quality is the key to the success of a company to achieve customer loyalty. Alnsour et al. (2014) reveal that every dimension of service quality affects customer loyalty positively. Huang (2009) measures service quality in airlines and states that every dimension of service quality except empathy has a significant positive effect on passenger loyalty or customer loyalty. Therefore, the sixth hypothesis developed is H6: Service quality has a positive influence on Customer Loyalty.

This research is replicating Calisir et al. (2016) research. This research states that customer satisfaction has no effect on customer loyalty. In addition, Leong et al. (2015) argue that customer satisfaction has an effect on customer loyalty. Considering these results' gap, this study is further carried out by replicating the research model of Calisir et al. (2016) on the Lion Air Indonesia airline. This study adds a customer loyalty variable that replicates Arif' (2015) study that reveals service quality is significantly related to customer loyalty. This study aims to determine and analyze the effects of price, service quality, customer satisfaction, and image on customer loyalty with the research object of Lion Air Indonesia.

\section{RESEARCH METHODS}

This This research is causal. The data used were primary data on the population of this study, namely customers who flew Lion Air airline services in the past two years, at least 18 years old, and domiciled in Indonesia. The sampling technique used in this study was non-probability sampling - convenience sampling. There were 271 questionnaires received online, but only 250 questionnaires can be processed. Data processing techniques used SEM-AMOS. Measurements of 
Price (P) and Service Quality (SA, SB, SC, $\mathrm{SD}, \mathrm{SE}$ ) replicate Calisir et al. 2016. Customer Satisfaction (CS) replicates Lin, Chen, \& Chiu (2010) instead of Calisir et al. (2016); Image (IM) replicates Tu et al. 2012 and Ofori et al. 2017 instead of Omoregie et al. (2018) and Customer Loyalty (CL) replicates Omoregie et al. 2018.

\section{RESULTS AND DISCUSSIONS}

Table 1. The measurement model: validity and reliability testing.

\begin{tabular}{|c|c|c|c|}
\hline Variable & Std. Load & AVE & CR \\
\hline $\mathrm{P} 1$ & 0.912 & 0.788 & 0.799 \\
\hline $\mathrm{P} 2$ & 0.908 & & \\
\hline P3 & 0.869 & & \\
\hline $\mathrm{P} 4$ & 0.862 & & \\
\hline SA1 & 0.885 & 0.778 & 0.958 \\
\hline $\mathrm{SA} 2$ & 0.877 & & \\
\hline SA3 & 0.886 & & \\
\hline SA4 & 0.865 & & \\
\hline SB1 & 0.861 & & \\
\hline SB2 & 0.873 & & \\
\hline SB3 & 0.859 & & \\
\hline SB4 & 0.859 & & \\
\hline SC1 & 0.887 & & \\
\hline $\mathrm{SC} 2$ & 0.878 & & \\
\hline SC3 & 0.878 & & \\
\hline $\mathrm{SC} 4$ & 0.863 & & \\
\hline SD1 & 0.885 & & \\
\hline SD2 & 0.883 & & \\
\hline SD3 & 0.894 & & \\
\hline SD4 & 0.886 & & \\
\hline SE1 & 0.866 & & \\
\hline SE2 & 0.875 & & \\
\hline SE3 & 0.875 & & \\
\hline SE4 & 0.866 & & \\
\hline SE5 & 0.891 & & \\
\hline SE6 & 0.98 & & \\
\hline SE7 & 0.87 & & \\
\hline CS1 & 0.867 & 0.744 & 0.749 \\
\hline $\mathrm{CS} 2$ & 0.863 & & \\
\hline $\mathrm{CS} 3$ & 0.859 & & \\
\hline IM1 & 0.876 & 0.766 & 0.749 \\
\hline IM2 & 0.88 & & \\
\hline IM3 & 0.87 & & \\
\hline CL1 & 0.893 & 0.785 & 0.833 \\
\hline CL2 & 0.871 & & \\
\hline CL3 & 0.899 & & \\
\hline CL4 & 0.87 & & \\
\hline CL5 & 0.897 & & \\
\hline
\end{tabular}

The results of the measurement model show the measurement goodness of fit (GFI) index, namely CMIN/DF $=1.421$ (Good Fit), RMSEA $=0.041$ (Good Fit), GFI $=0.835$ (Marginal Fit), TLI = 0.977 (Good Fit), and $\mathrm{CFI}=0.979$ (Good Fit). A variable measurement indicator is declared valid if the value of the minimum standardized factor loading $(\lambda)$ or the value of average variance extracted (AVE) is 0.5. Internal consistency variable reliability testing is indicated by the minimum construct reliability (CR) value of 0.7. This signifies that the data used in this study has gone through the correct measurement stage, so it is feasible to continue to the hypothesis testing stage.

The structural model suitability test shows the measurement model results which show the measurement goodness of fit (GFI) index, namely CMIN / DF $=1.421(\mathrm{Good}$ Fit), RMSEA $=0.041$ (Good Fit), GFI = 0.835 (Marginal Fit), TLI $=0.977($ Good Fit), and CFI $=0.979$ (Good Fit).

Table 2. Hypothesis testing results.

\begin{tabular}{lcccc}
\hline Path & Std.Est. & C.R & P & Remark \\
\hline P $\rightarrow$ CS & 0.452 & 2.454 & 0.014 & supported \\
SQ $\rightarrow$ CS & 0.537 & 2.860 & 0.004 & supported \\
CS $\rightarrow$ IM & 0.996 & 18.823 & $* * *$ & supported \\
CS $\rightarrow$ CL & 3.370 & -599 & 0.549 & not supported \\
IM $\rightarrow$ CL & 3.491 & 0.618 & 0.537 & not supported \\
SQ $\rightarrow$ CL & 0.854 & 2.094 & 0.036 & supported \\
\hline
\end{tabular}

Hypothesis 1 test shows that price has a positive and significant effect on customer satisfaction of Lion Air in Indonesia. This is in line with Calisir et al. (2016) research that states that price affects customer satisfaction. The lower the price, the more satisfied the customer will be.

Service quality has a positive and significant impact on customer satisfaction $(\mathrm{H} 2)$ of Lion Air Indonesia. This is in line with Calisir et al. (2016), which state that service quality has a significant relationship with customer loyalty. If the perceived service is equal to or greater than the expected service, the customer will be satisfied (Gronroos 1984).

Hypothesis 3 test shows that customer satisfaction has a positive and significant ef- 
fect on the image of Lion Air Indonesia. The more satisfied the customer, the better the image formed by the company. This is in line with research conducted by Calisir et al. (2016), which states that customer satisfaction has an effect on the image. From this research, it is found that the image is described with satisfaction, signifying that satisfaction is one of the factors forming the company's image in the minds of customers.

Hypothesis 4 test shows that customer satisfaction has no effect on customer loyalty of Lion Air Indonesia. This is in line with Calisir et al. (2016) research that states that customer satisfaction has no effect on customer loyalty. The results of these studies differ from the findings of Akamavi et al. (2015), Forgas et al. (2010), and Namukasa (2013) that reveal satisfaction is significantly related to loyalty. Customer satisfaction has no effect on customer loyalty due to other factors where customers consider the differences between airline companies, flight routes, and regions (Calisir et al. 2016).

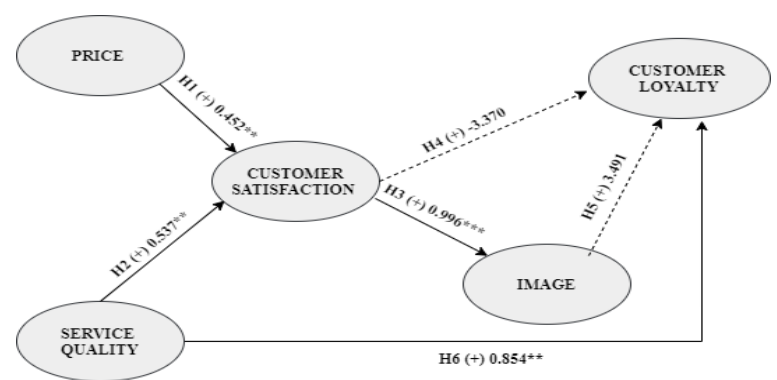

Figure 1. The result of the structural modeling testing. $* *$ Significant coefficient $\mathrm{p}$-value $\leq 0.05$. *** Significant coefficient $p$-value $\leq 0.01$. The figure listed is the standardized estimate. The dashed line is an unsupported hypothesis

Hypothesis 5 test shows that image has no effect on customer loyalty of Lion Air Indonesia. This finding is in line with the research of Omoregie et al. (2018). A good company image is not necessarily the reason customers can use the airline's services for a long time. This is because customer needs for these flights are different.

Hypothesis 6 test shows that service quality has a positive and significant effect on customer loyalty of Lion Air Indonesia. This is in line with the research of Matos \& Rossi (2009), which shows that service quality is known as a significant determinant of customer loyalty. Therefore, it can be said that the quality of service is related to the customer's decision to continue choosing Lion Air as one of the airlines that will be used now and in the future. Omoregie et al. (2018) state that service quality has a significant effect on customer loyalty.

\section{CONCLUSION}

This In conclusion, the study has 4 supported hypotheses and 2 unsupported hypotheses, as follows: 1. Price affects Customer Satisfaction of Lion Air Indonesia. 2. Service Quality affects Customer Satisfaction of Lion Air Indonesia. 3. Customer Satisfaction affects the image of Lion Air Indonesia. 4. Customer Satisfaction has no effect on Customer Loyalty of Lion Air Indonesia. 5. Image has no effect on customer loyalty of Lion Air Indonesia. 6. Service Quality affects Customer Loyalty of Lion Air Indonesia.

A suggestion for future research is to carry out the same study on several other LCC (Low-Cost Carrier) domestic airlines to increase the number of research objects. This study only uses 5 variables to determine the effects on customer loyalty; thus, it is hoped for further research to add other variables such as trust and perceived value to understand customer loyalty better.

\section{REFERENCES}

Akamavi, R. Mohamed, E. Pellmann, K. \& Xu, Y. 2015. Key determinants of passenger loyalty in the low-cost airline business. Tour Management: 528-545.

Alnsour, M.S. Tayeh, B.A. \& Alzyadat, M.A. 2014. Using SERVQUAL to Assess the Quality of Service Provided by Jordanian Telecommunications Sector. International Journal of Commerce: 209218.

Arif, M. 2015. Analisa kualitas pelayanan, Citra terhadap kepuasan pelanggan dan loyalitas pelanggan. Jurnal Jom FEKOM 2(2): 1-15.

Calisir, N. Basak, E. \& Calisir, F. 2016. Key drivers of passenger loyalty: A case of FrankfurteIstanbul 
flights. Journal of Air Transport Management: 211-217.

Clemes, M.D. Gan, C. Kao, T.H. Choong, M. 2008. An empirical analysis of customer satisfaction in international air travel. Innovative Market 4: 5062.

Cronin, J. Michael, K. Brady, M.K. \& Hult, G.T. 2000. Assessing the effects of quality, value, and customer satisfaction on consumer behavioral intentions in service environments. Journal of Retailing 76(2): 193-218.

Cronin, J. \& Taylor, S.A. 1992. Measuring service quality: A re-examination and extension. Journal of Marketing 56: 55-67.

Davidow, M. 2003. Have you heard the word? The effect of word of mouth on perceived justice, satisfaction and repurchase intentions following complaint handling. Journal of Consumer Satisfaction, Dissatisfaction and Complaining Behavior 16(1): 67-80.

Ekiz, H.E. \& Arasli, H. 2007. Measuring the impacts of organizational responses: Case of Northern Cyprus hotels. Managing Global Transitions: International Research Journal 5(3): 271-287.

Forgas., A.M. 2010. Antecedents of airlines passenger loyalty: low cost versus traditional airlines. Journal Management Air Transportation 16(4): 229-233.

Gronroos, C. 1984. A service quality model and its marketing implications, Europ. Journal Marketing 18(4): 36-44.

Huang, K. 2009. The effect of airline service quality on passenger behavioral intentions using SERVQUAL scores; A Taiwan case study. Journal of The Eastern Asia Society for Transportation Study 8: 2301-2314.

Legoherel, P. 1998. Quality of tourist services: The influence of each participating component on the consumer's overall satisfaction regarding tourist services during a holiday. In Proceedings of $3 \mathrm{rd}$ international conference on tourism and hotel industry in Indo-China and Southeast Asia: Development, marketing and sustainability. Thailand

Leong, L.Y. Hew, T.S. Lee, V.H. \& Ooi, K.B. 2015. An SEM-artificial-neural-network analysis of the relationships between SERVPERF, customer satisfaction and loyalty among lo-cost and fullservice airline. Expert System with Applications 42(19): 6602-6634.

Saha, G.C. \& Theingi. 2009. Service quality, satisfaction, and behavioral intentions: A study of lowcost airline carriers in Thailand. Managing Service Quality 19(3): 350-371.

Stevens, P. Knutson, B. \& Patton, M. 1995. DINESERV: A tool for measuring service quality in restaurants. The Cornell Hotel and Restaurant Administration Quarterly 5: 56-60.

Matos, C.A. \& Rossi, C.A.V. 2008. Word-of-Mouth Communications in Marketing: A Meta-Analytic Review of the Antecedents and Moderators. Jour- nal of the Academy of Marketing Science 36(4):578-596.

Mikulic, J. \& Prebezac, D. 2011. What drives passenger loyalty to traditional low-cost airlines? A formative partial least squares approach. Journal Air Transportation Management 17(4): 237-240.

Munusamy, J. Chelliah, S. Pandian, S. Business, F. Street, K. 2011. Customer satisfaction delivery in airline industry in Malaysia: a case of low-cost carrier. Aust. J. Basic Appl. Sci. 5 (11): 718-723.

Nadiri, H. Hussain, K. Ekiz, E.H. \& Erdogan, S. (2008). An investigation on the factor influencing passengers' loyalty in the North Cyprus national airline. TQM Journal 20(3): 265-280.

Namukasa, J. 2013. The Influence of airlines service quality on passenger satisfaction and loyalty, In: Mutury, D. (ed). The TQM Journal 25(5): 520532.

Omoregie, O.K. Addae, J.A. Coffie, S. Ampong, G.O. \& Ofori, K.S. 2019. Factors influencing consumer Loyalty: evidence from the Ghanaian retail banking industry. International Journal of Bank Marketing: 798-819.

Vlachos, I. \& Lin, Z. 2014. Drivers of airline loyalty: evidence from the business travelers in china. Transp. Res. Part E logist, Transp Res 71: 1-17 